\title{
Assessment of avoidable losses and economic injury levels for the sorghum head bug, Callocoris angustatus Leth. (Hemiptera:Miridae) in India
}

\author{
H. C. SHARMA AND V. F. LOPIZZ \\ Intcralional Crops Research Institule for the Semi-Arid Tropics (ICRISAT), Palancheru P.O., \\ A.P. 50! 3 '3. $\cdot$, India
}

\begin{abstract}
Austrater. Avoidable losses and economic injury levels (EILs) were computed lor the sorghum head buge, Calocoris angustatus Leth., on three cultivars during three rainy seasons (1985-1987) at ICR ISAT. Grain yield in plots protected with $2-5$ insecticicle sprays (carbaryl at 500 g a.i./ha) between the half-antlekis and the dough stitge was significantly higher than in untreated plots, with cost benefit rat ioss > 1. Plots that were not protected at hall-anthesis and/or complete-antlesis, and at milk and dough statges, suffered a signilicant loss in yield. Bug damage spoiled the grain quality in terms of germination, 1000 -grain mass, grain hardness and percentage floaters. Tliree (10 four sprays between complete-inthesis and the dough stige prevented at significant reduction in grain quality. Head bug density at half-anthesis, complete-inthesis, milk and dough stages was signilicantly and negatively associated with grain yield. Bug density at diflerent statges explained $4: 3 \% 4 \%$ of the variance in yield. Direct effects of bug numbers at the milk stage and the indirece elfects of head bug density at other stages through the milk stage contributed towards maximum reduction in yield. Maximum avoidable losses were recorded in cultivar ICSV $1(88.6 \%)$, followed by CSH $1(69.9 \%)$, and C.SH $5(53.9 \%$ in 1986 and $55.0 \%$ in 1987$)$. Loss in gratin yield/ha due to one insect/panicle at hall-anthesis and that based on natural increase, were 548 and $232 \mathrm{~kg}$ in CSIH 5 during 1986 and 1987, respectively, $251 \mathrm{~kg}$ in ICSV 1, and $77 \mathrm{~kg}$ in CSH 1. EILs based on a cost-benteft ratio of $1: 1$ ranged from 1.3 1.4 insects/panicle for CSH 1, 0.4 for ICSV 1, and (0.t-0.6 and 0.2-0.4 for CSH 5 during 1986 and 1987, respectively. Simple cosi estimates for insecticide sprays and the resultant saving in grain yield are a useful tool for decision-making in pest matnagement.
\end{abstract}

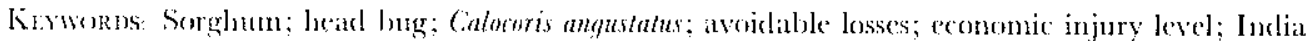

\section{Introduction}

Sorghum (Sorghum bicolor (L.) Moench.) is one of the most important cercal crops in Asia, Africa, and Latin America. Grain yields on peasant farms are generally low, partly because of insect pests (Sharma, 1985a). Nearly $32 \cdot 1 \%$ of the production is lost because of insect pests (Borad and Mittal, 1983). Panicle-feeding insects alone result in an annual loss of nearly US $\$ 100$ million in India (Leuschner and Sharma, 1983).

Calocoris angustalus is one of the most important pests of grain sorghum in India. Adults and nymples feed on the endosperm of the developing grain from anthesis to the hard-dough stage, and this results in severe loss in grain yield and quality (Sharma, 1985b).

Avoidable losses and economic injury levels (EILs) have been determined lor relatively few pests, although these are central issues in decision-making in pest management. The problem lies in adopting an appropriate methodology to compute losses, and the variation in the cost of inputs and the associated savings in yield (Pedigo, Hutchins and Higley, 1986). In sorghum, ElLs have been reported for shoot fly, midge, armyworm, and some coreid and penta- tomid bugs (Hall and Teetes, 1982), but not for mirid head bugs. This paper reports the results of studies on the losses and EILs for C. angustatus on three sorghum cultivars. An attempt has also been made to compute EILs from a cost-benelit ratio of $1: 1$, based on one insect atcross all panicle developmental stages or by following the natural increase of bugs. EILs were also computed by the formula of Norton (1976) and compared with those calculated from cost-benefit ratios.

The loss of grain quality due to clamage by head bugs is important. Endosperm texture is an important charateristic in food preparation. Vitreous and hard endosperm is prelerred for several porridges (Rooncy and Murty, 1982). Bug feeding increases amylase activity, and severely affects the grain quality, both physically and biochemically. During the rainy season, bue feeding renders the grain susceptible to mould infection, causing further deterioration in grain quality. Bug damage changes the ondosperm texture and spoils the grain quality. Data were recorded on 1000-grain mass, grain hardness, percentage floaters and percentage germination, to evaluate the effect of bug damage on grain quality during the 1987 rainy season. 


\section{Materials and methods}

\section{Effect of different spray schedules on head bug numbers and grain yield}

Studies were carried out at ICR ISA' during three rainy seasons (1985-1987), with sorghum cultivars ICSV 1 and CSH 1 studied in 1985, and CSH 5 in 1986 and 1987. The crop was planted on ridges $75 \mathrm{~cm}$ apart, and the seedlings were thinned to a $10 \mathrm{~cm}$ spacing within the row 15 days after emergence. Carbofuran $3 \mathrm{G}$ at $40 \mathrm{~kg} / \mathrm{ha}$, i.e. $1.2 \mathrm{~kg}$ a.i./ha, was applied at the time of planting to protect the crop from shoot lly and stem borer damage. Two infester rows of hybrids CSH 1 and CSH 5 were planted every eight test rows 20 days before the experimental plots. Each plot measured $6 \times 9 \mathrm{~m}$. The experiments were laid out in a randomized block design and there were four replications. Head bugs collected from other fields were uniformly spread in the infester rows at panicle emergence. 'The bugs multiplied lor one generation and then moved to the test plots. This provided uniform infestation and increased the head bug population in the experimental plots.
Carbaryl (1-naphthyl methylcarbamate) at $500 \mathrm{~g}$ a.i./ha was sprayed at $5001 /$ ha with a knapsack sprayer, with a hollow cone nozzle, and a pump pressure of $2.5-3.0 \mathrm{~kg} / \mathrm{cm}^{2}$. $\Lambda$ polycthylene screen $(2 \times 2 \mathrm{~m})$ was held downwind to minimize drift to adjacent plots. The spray schedules are given in Tables $1-4$.

Head bugs were counted in 10 randomly selected panicles in each plot $24 \mathrm{~h}$ after each spraying during 1985, and 24 h before and after each spraying cluring 1986 and 1987, at different stages of panicle development. $\Lambda$ t maturity, sorghum panicles from the central four rows of each plot were harvested for grain yield.

Data on bug numbers and grain yield were subjected to analysis of variance, and the treatment means were compared using the least significant difference (LSD). Corrclation and regression coefficients of bug numbers and grain yield at different stages of panicle development were computed. The data were also subjected to path cocfficient analysis to determine the direct and indirect effects of bug numbers at different stages of panicle development on grain yield.

TaBle: 1. Effect of carbaryl sprays on head bug numbers and grain yield at different stages of panicle development in CosH l (1985 rainy season

\begin{tabular}{|c|c|c|c|c|c|c|c|}
\hline \multirow[b]{2}{*}{ 'Ireatment } & \multicolumn{5}{|c|}{ No, of head bugs / panicte alter spraty } & \multirow{2}{*}{$\begin{array}{c}\text { Grain yield } \\
\text { (kg/ha) }\end{array}$} & \multirow{2}{*}{$\begin{array}{c}\text { Cosl benclit } \\
\text { ratio }\end{array}$} \\
\hline & HA & $\mathrm{CA}$ & $\mathrm{M}$ & $\mathrm{D}$ & $\mathrm{HD}$ & & \\
\hline $\mathrm{IIHA}$ & $0 \cdot 3(0 \cdot 4)^{h}$ & $3 \cdot 6(1 \cdot 8)$ & $2] \cdot 7(1 \cdot 6)$ & $81-6(8 \cdot 7)$ & $\cdot+7(2 \cdot 1)$ & $1 \cdot 109$ & $1: 9.0$ \\
\hline $\mathrm{I}^{2} \mathrm{HA}+\mathrm{CA}$ & $0 \cdot 1(0 \cdot 2)$ & $0 \cdot 1(0 \cdot 3)$ & $2 \cdot 0(1 \cdot 4)$ & $16-3(3-9)$ & $5 \cdot(0)(2 \cdot 2)$ & 1605 & $1: 5 \cdot 5$ \\
\hline $\mathrm{T} 3 \mathrm{HA}+\mathrm{CA}+\mathrm{M}$ & $0 .+10 \cdot 6)$ & $(0 \cdots+(0 \cdot 6)$ & $(0.4(0.5)$ & $18 \cdot 7(\cdot 1 \cdot 0)$ & $4 \cdot 0(2) \cdot(0)$ & $1+496$ & 1: 3.3 \\
\hline $\mathrm{I}+\mathrm{HA}+\mathrm{CA}+\mathrm{M}+\mathrm{D}$ & $0 \cdot 0(0 \cdot 0)$ & $0.3(0.5)$ & $0.5(0.7)$ & $1 \cdot 5(1 \cdot 1)$ & $1 \cdot 3(0 \cdot 9)$ & 11.59 & $1: \quad 1.6$ \\
\hline $\mathrm{T} 5 \mathrm{HA}+\mathrm{CA}+\mathrm{M}+\mathrm{D}+\mathrm{HD}$ & $0 \cdot 2(0 \cdot 3)$ & $(0 \cdot 1 \cdot(0 \cdot 6)$ & $0 \cdot 4 \cdot(0 \cdot 5)$ & $2 \cdot 7(1 \cdot 6)$ & $0.0(0)(0 \cdot 0)$ & 1678 & I: 2.4 \\
\hline $\mathrm{I} 6 \mathrm{CA}+\mathrm{M}+\mathrm{D}+\mathrm{HD}$ & $7 \cdot 0(2 \cdot 6)$ & $0 \cdot 2(0 \cdot+4)$ & $0 \cdot 5(0 \cdot 6)$ & $2 \cdot 5(1+4)$ & $0.3(0.5)$ & 1383 & $1: 2.2$ \\
\hline $\mathrm{T} 7 \mathrm{M}+\mathrm{D}+\mathrm{HD}$ & $+7 \cdot 7(2 \cdot 1)$ & $15 \cdot 3(3 \cdot 8)$ & $0.3(0.5)$ & $1 \cdot 1\} 1 \cdot 0\rangle$ & $0.2\{0.3\}$ & 1575 & $1: \quad 3 \cdot 6$ \\
\hline I'8 D + HD & $5 \cdot 6(2 \cdot 3)$ & $18 \cdot 3(\cdot 1 \cdot 1)$ & $56 \cdot 3(7 \cdot 3)$ & $1 \cdot 0(0-9)$ & $0.3\{0 \cdot 4\}$ & 653 & $1: 0.8$ \\
\hline $19 \mathrm{HD}$ & $11 \cdot 7(3 \cdot 0)$ & $22 \cdot 0(\cdot+\cdot 1)$ & $(04.0)(7.9)$ & $65 \cdot 0\langle 8 \cdot 0\rangle$ & $0.3(0 \cdot 4)$ & +55 & $1:-0.5$ \\
\hline Tlo Lintreated-etueck & $13 \cdot 7(3 \cdot 7)$ & $10 \cdot 3(3 \cdot 1)$ & $51 \cdot 3(7 \cdot 1)$ & $61 \cdot 0(7 \cdot 7)$ & $6 \cdot 0(2 \cdot 2)$ & 50.5 & $\cdots$ \\
\hline $\mathrm{SE}$ & $\pm(0 \cdot 36)$ & $\pm(0.47)$ & $\pm(0.51)$ & $\pm(0.76)$ & $\pm\{0-31\}$ & $\pm 106 \cdot 8$ & \\
\hline
\end{tabular}

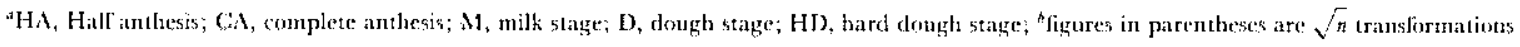

'TABLE: 2. EJlect of carbatyl sprays on head bug numbers and grain yield at different stages of panicle devetopment in ICSV 1 〈 1985 rainy season

\begin{tabular}{|c|c|c|c|c|c|c|c|}
\hline \multirow[b]{2}{*}{ Treatment } & \multicolumn{5}{|c|}{ No. ol head bugs / panicle alter spraty } & \multirow{2}{*}{$\begin{array}{c}\text { Grain yicld } \\
\{\mathrm{kg} / \mathrm{hat}\}\end{array}$} & \multirow{2}{*}{$\begin{array}{c}\text { Cost bemefit } \\
\text { ratlo }\end{array}$} \\
\hline & $\mathrm{HA}$ & C:A & $\mathrm{M}$ & D & $\mathrm{HI}$ & & \\
\hline Il HA & $1.9(1.3)^{b}$ & $0.8(0 \cdot 9)$ & $12.7(3.1)$ & $6 \cdot 7(2 \cdot 4)$ & $0 \cdot 1 \cdot(0 \cdot 2)$ & 2366 & $1: 20 \cdot 1$ \\
\hline $\mathrm{I}^{2} \mathrm{HA}+\mathrm{CA}$ & $1.7(1.1)$ & $0 \cdot 3(0 \cdot 4)$ & $0.8(0.9)$ & $2.5(1.5)$ & $1 \cdot 1(0 \cdot 6)$ & $2 \cdot 1.51$ & $1: 10 \cdot 8$ \\
\hline $\mathrm{I} 3 \mathrm{HA}+\mathrm{CA}+\mathrm{M}$ & $0.5(0 \cdot 6)$ & $0 \cdot 4(0 \cdot 6)$ & $0 \cdot 3(0 \cdot 3)$ & $5 \cdot 0(1.5)$ & $0 \cdot 5(0.3)$ & 22.53 & $1: 6 \cdot 5$ \\
\hline $\mathrm{I} \div \mathrm{HA}+\mathrm{CAA}+\mathrm{M}+\mathrm{D}$ & $1 \cdot 3(0 \cdot 8)$ & $0 \cdot 4(0 \cdot 6)$ & $0 \cdot 0(0 \cdot 0)$ & $0.1(0.1)$ & $0 \cdot 1(0 \cdot 2)$ & 2599 & $1: 5 \cdot 8$ \\
\hline $\mathrm{I} 5 \mathrm{HA}+\mathrm{CA}+\mathrm{M}+\mathrm{D}+\mathrm{HD}$ & $3 \cdot 6(1 \cdot 7)$ & $5 \cdot 2(1 \cdot 6)$ & $0.1(0.1)$ & $0 \cdot](0 \cdot 1)$ & $(0 \cdot 1(0.2)$ & 2161 & $1: 3 \cdot 7$ \\
\hline $\mathrm{I} 6 \mathrm{CA}+\mathrm{M}+\mathrm{D}+\mathrm{HD}$ & $17 \cdot 5(4 \cdot 1)$ & $0.7(0.8)$ & $0.3(0.5)$ & $0 \cdot 2(0 \cdot 3)$ & $0 \cdot 1(0.2)$ & 1895 & $1:+4)$ \\
\hline $\mathrm{I} 7 \mathrm{M}+\mathrm{D}+\mathrm{HD}$ & $12 \cdot 5(3 \cdot 4)$ & $38 \cdot 7(6 \cdot 1)$ & $0.7(0.7)$ & $(0.0)(0 \cdot 0)$ & $0.0(0.0)$ & 469 & $1: 0.6$ \\
\hline${ }^{\top} 8 \mathrm{D}+\mathrm{HD}$ & $11.0(3.2)$ & $22.7(4.8)$ & $87.2(9.3)$ & $0.1(0.3)$ & $(0 \cdot 0(0 \cdot 0)$ & 296 & $1: 0 \cdot 0$ \\
\hline I'9 HD & $11 \cdot 0(3.2)$ & $19 \cdot 1(3.3)$ & $89.5(9 \cdot 1)$ & $10.5(2.8)$ & $0.0(0.0)$ & 587 & $1: 2-9$ \\
\hline 'T'10 Untreated-check & $9 \cdot 7 \cdot(2.9)$ & $3 \cdot 2 \cdot 2(5 \cdot 3)$ & $159 \cdot 2(12 \cdot 4)$ & $4 \cdot 2(2 \cdot 0)$ & $(0 \cdot 0(0 \cdot 0)$ & 296 & $\ldots$ \\
\hline SE & $\pm(0 \cdot 40)$ & $\pm(0.75)$ & $\pm(0.70)$ & $\pm(0 \cdot 1 \cdot 1)$ & $\pm(0.2 !)$ & \pm 199.1 & \\
\hline
\end{tabular}

a.b. As in Table 1 


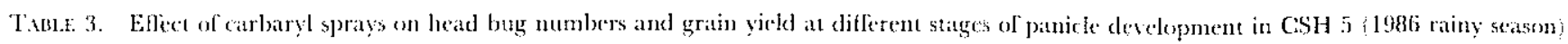

\begin{tabular}{|c|c|c|c|c|c|c|c|c|}
\hline \multirow[b]{3}{*}{ Trtatment } & \multicolumn{6}{|c|}{ No. ol head bugs / panicke } & \multirow{3}{*}{$\begin{array}{l}\text { Grain } \\
\text { yield } \\
\text { lgg/hit }\end{array}$} & \multirow{3}{*}{$\begin{array}{l}\text { Cost } \\
\text { binelit } \\
\text { ratioo }\end{array}$} \\
\hline & \multicolumn{2}{|c|}{ Cid } & \multicolumn{2}{|c|}{$M$} & \multicolumn{2}{|c|}{$\mathrm{D}$} & & \\
\hline & $\begin{array}{l}\text { Be[ore } \\
\text { sprayy }\end{array}$ & $\begin{array}{l}\text { After } \\
\text { siprity }\end{array}$ & $\begin{array}{l}\text { Before } \\
\text { spraty }\end{array}$ & $\begin{array}{l}\text { Alter } \\
\text { spray }\end{array}$ & $\begin{array}{l}\text { Before } \\
\text { spray }\end{array}$ & $\begin{array}{l}\text { Afier } \\
\text { spray }\end{array}$ & & \\
\hline lla & $7 \cdot 7 ! 2 \cdot 7 !^{4}$ & {$[\cdot 4+1 \cdot 1$} & $+0\{1 \cdot 9\}$ & $11 \cdot 0\{3 \cdot 2\}$ & $11 \cdot 23 \cdot 3$ & $5 \cdot 5 \div 2 \cdot 3:$ & 2770 & $1: 1+14$ \\
\hline$T C A+N$ & $8 \cdot 5 \div 29$ & $0.8\{0.9\}$ & $8 \cdot 0(2.7)$ & $0.5(0.6)$ & $2.5(1 \cdot 5)$ & $1.5 \div 1.2 !$ & 2760 & $1: 7 \cdot 1 \cdot 4$ \\
\hline $13 C A+M+1)$ & 9.233 .0 & $0 \cdot+10+1$ & $3 \cdot 2(1 \cdot 8)$ & $1 \cdot 1100$ & $8 \cdot 2(2+1)$ & $0 \cdot 6 \div 0 \cdot 8$ & 2903 & $1: 5.15$ \\
\hline $\mathrm{T}+\mathrm{M}+\mathrm{D}$ & $83 \cdot 26.8$ & $7.5 \div 2.7$ & $52 \cdot 266 \cdot 9\}$ & $1 \cdot 1[1 \cdot 0)$ & 4.01 .83 & 0.010 .0 & 2426 & $1: 5.94$ \\
\hline $\mathrm{T} 5 \mathrm{D}$ & $7 \cdot 2\{26)$ & $5 \cdot 2\{2-2\}$ & $.56 \cdot 0<7 \cdot 4)$ & $92.7(8.9)$ & $51 \cdot 76 \cdot 6)$ & 0.606 & 1531 & $1: 1.92$ \\
\hline I'6 Untreated-check & 11.013 .2 & $4 \cdot 5(2 \cdot 1)$ & $60 \cdot 7\langle 7 \cdot 6\rangle$ & $70 \cdot 5(8 \cdot 3)$ & $57 \cdot 0(7 \cdot 1)$ & $31 \cdot 5(5 \cdot 4)$ & 1339 & $1: 1.00$ \\
\hline$S \mathrm{SL}$ & $\pm(0.19$ & $\pm\{0.19\}$ & $\pm\{0.59\}$ & \pm 0.96 & $\pm\{0.76\}$ & $\pm(0.53)$ & $\pm 172 \cdot 8$ & \\
\hline
\end{tabular}

ans in Ithle !

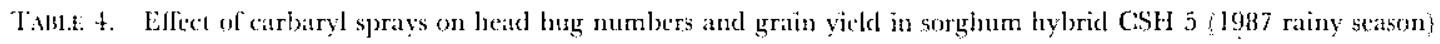

\begin{tabular}{|c|c|c|c|c|c|c|c|c|c|c|}
\hline \multirow[b]{3}{*}{ Ireatment } & & \multicolumn{6}{|c|}{ No. of lecad bugs / panicle } & \multicolumn{3}{|c|}{$=$} \\
\hline & \multicolumn{2}{|c|}{$\mathrm{HA}$} & \multicolumn{2}{|c|}{ CA } & \multicolumn{2}{|c|}{ 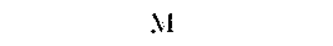 } & \multicolumn{2}{|c|}{ D) } & \multirow{2}{*}{$\begin{array}{l}\text { Grain } \\
\text { ytutd } \\
(\mathrm{kg} / \mathrm{hil})\end{array}$} & \multirow{2}{*}{$\begin{array}{l}\text { Cost- } \\
\text { beneflit } \\
\text { rittio }\end{array}$} \\
\hline & $\begin{array}{l}\text { Before } \\
\text { sprity }\end{array}$ & $\begin{array}{l}\text { Afier } \\
\text { spray }\end{array}$ & $\begin{array}{l}\text { Before } \\
\text { spray }\end{array}$ & $\begin{array}{l}\text { Alter } \\
\text { sprity }\end{array}$ & $\begin{array}{l}\text { Before } \\
\text { spray }\end{array}$ & $\begin{array}{l}\text { After } \\
\text { sprayy }\end{array}$ & $\begin{array}{l}\text { Before } \\
\text { sprity }\end{array}$ & $\begin{array}{l}\text { After } \\
\text { sprily }\end{array}$ & & \\
\hline II HA" & $1 \cdot 4(2 \cdot 1)^{b}$ & $0.0(0) 0.0$ & $11 \cdot 0\{3 \cdot 2\}$ & $3.0(1 \cdot 6)$ & $158.0(12.2)$ & $96 \cdot(0\langle 9.7)$ & $5+4 \cdot 0(7 \cdot 3)$ & $12 \cdot 5\langle 3.3\rangle$ & 2170 & $1: 10.95$ \\
\hline $1: H A+C A$ & $5 \cdot 0(2 \cdot 2)$ & $(0 \cdot 0(0) 0$ & $7 \cdot 0\{2 \cdot 6\}$ & $0.0(0.0)$ & $22 \cdot 0 \quad(4.5)$ & $8 \cdot 0\{2 \cdot 8\}$ & $16.0(+4)$ & $9.0(2.9)$ & 2388 & $1: 6.57$ \\
\hline $13 H A+(A A+M$ & $6 \cdot 0\{2 \cdot 3\}$ & $0.0[0.0)$ & $12.0\{3 \cdot 2\}$ & $0.0(0.0)$ & $15-0(3.8)$ & $2-0(1-5\}$ & $17 \cdot 0(* \cdot 1)$ & $8 \cdot 0(2 \cdot 8)$ & 2128 & 1: 3.51 \\
\hline $\mathrm{H}+\mathrm{HA}+\mathrm{CA}+\mathrm{M}+\mathrm{D}$ & $3.0(1.8)$ & $0.0(0.0)$ & $11 \cdot 0(3 \cdot 2)$ & $0.0(0.0)$ & $9.0)(2.9)$ & $3.0(1.5)$ & $8 \cdot 0(2+8)$ & $2.2\{1.5\}$ & 2633 & 1: 3.90 \\
\hline $15(A+N+1)$ & $5 \cdot 0(2 \cdot 2)$ & $5 \cdot 0(2.2)$ & $10 \cdot 0(3 \cdot 1)$ & $0.0(0.0)$ & $15 \cdot 0\langle 3.8\}$ & $3 \cdot 0\{1-6\}$ & $5 \cdot 0(2.2)$ & $2 \cdot 0)(1 \cdot 3)$ & 2351 & $1: \cdot 1 \times 25$ \\
\hline$\Gamma 6 \mathrm{M}+\mathrm{D}$ & $5 \cdot(3(2-2)$ & $4-(0(2 \cdot 1)$ & $17 \cdot 0(2 \cdot 6)$ & $3(0 \cdot 0)(5 \cdot 7)$ & $182 \cdot 0(12 \cdot 5)$ & $+40(2 \cdot 0)$ & $7 \cdot 0(2 \cdot 6)$ & $1 \cdot 2(1 \cdot 4)$ & 1770 & 1: $3 \cdot 48$ \\
\hline $17 \mathrm{D}$ & $5 \cdot 0(2 \cdot 2)$ & $5 \cdot 0(2 \cdot 1)$ & $7 \cdot 0(2 \cdot 6)$ & $37 \cdot(0)(5 \cdot 7)$ & $161 \cdot 0(12.5)$ & $65 \cdot 0)(8 \cdot 0)$ & $32 \cdot 0(6.0)$ & $2 \cdot 2(1 \cdot 4)$ & 1150 & $1: 0.75$ \\
\hline T8 Untreated cluetk & $5 \cdot()(2) \cdot 2)$ & $5 \cdot 0(2 \cdot 1)$ & $10 \cdot 0(3 \cdot 1)$ & $35 \cdot 0(5 \cdot 6)$ & $165 \cdot 0(12 \cdot 5)$ & $111(10 \cdot 4)$ & $30 \cdot 0(5 \cdot 3)$ & $8 \cdot 0 ! 2 \cdot 7)$ & 1075 & \\
\hline $\mathrm{SE}$ & $\pm(0-20)$ & $\pm(0 \cdot 20\}$ & $\pm(0 \cdot 57)$ & $\pm(0.72)$ & $\pm(0.98)$ & $\pm(0.59)$ & $\pm(0 \cdot 12)$ & $\pm(0 \cdot 32)$ & $\pm 170 \cdot 1$ & \\
\hline
\end{tabular}

As in Thlhe 1

\section{Effect of htad bug damage on grain quality}

During the 1987 rainy season, grain from different treatments was given various quality tests. One hundred grains were taken at random from each replication and placed in the folds of moist filter paper in a Petri dish at $25 \pm 2^{\circ} \mathrm{C}$ for a germination test. The paper was moistened every $24 \mathrm{~h}$ and the number of grains that germinated counted after $72 \mathrm{~h}$.

Thousand-grain samples were taken at random with an automatic grain counter and equilibrated overnight for moisture content in an oven at $37^{\circ} \mathrm{C}$. Grain mass was recorded the following day, and the samples were subjected to a grain-floater test to evaluate the eflect of bug damage on grain density. We followed the procedure of Hallgren and Murty (1983) and conducted the test using a sodium nitrate solution of specific density $1 \cdot 31$. Very lew grains of the test cultivar, CSH 5, settled at the bottom in sodium nitrate solution, so we compared the percentage floaters in plain water, which has a specific density of $1 \cdot 0$. The heavy grains settling at the bottom were removed and dried overnight at $40^{\circ} \mathrm{C}$. The mass of the heavy grains was recorded and expressed as a percentage of the total grain mass.
Grain hardness was recorded on the Kiya ${ }^{(6)}$ rice hardness tester. Twenty-five grains selected at random were tested for hardness in each replication. Moisture content was equilibrated in an oven at $37^{\circ} \mathrm{C}$ lor $24 \mathrm{~h}$ before the test. The maximum force required to break an individual grain was recorded as the hardness score. Data were analysed statistically to compute the least significant difference between treatments. Correlation coefficients between grain quality parameters were also computed.

\section{Avoidable losses}

Avoidable losses were computed from the grain yield recorded in untreated check plots and those receiving maximum protection against bugs. Avoidable losses (C) were computed by:

$$
C=\frac{(a-b)}{a} \times 100
$$

where $C=$ avoidable loss $(\%) ; a=$ grain yield in protected plots, and $b=$ grain yicld in unprotected plots. 


\section{Economic injury level (EIL)}

Economic injury levels were computed from a cost-benefit ratio of $1: 1$, that is when the cost of control was equal to the value of the grain saved. EILs were based on one insect per panicle across all stages of panicle development, and on the rate of natural increase in the untreated check plots. For example, in CSH 1 the rate of natural increase of head bugs in the untreated control plots was $1,0.8$, $3 \cdot 7,4 \cdot 5$ and $0 \cdot 4$ insects/panicle at the hall-anthesis, complete-anthesis, milk, dough and hard-dough stages, respectively. The loss in grain yield from one insect per panicle at half-anthesis was computed by using the rate of natural increase of bugs at different stages in the regression equation (Tables 7 and 9).

EILs were also computed by the formula of Norton (1976), as discussed by Pedigo et al. (1986):

$$
\operatorname{EIL}(Q)=\frac{C}{P \times D \times K}
$$

where $C=$ cost of insecticide use per hectare,

$P=$ price of produce/quintal fone quintal (q) $=100 \mathrm{~kg}$.

$D=$ loss in grain yield ( $\mathrm{q} / \mathrm{ha}$ ) associated with one insect/panicle, and

$K=$ reduction in pest altack $(0 \cdot 80)$.

\section{Results}

Effect of different spray schedules on head bug numbers and grain yield

During the 1985 rainy scason, bugs remained under check in plots sprayed at hall-anthesis and/or complete-anthesis to hard-dough stage (treatments T'2 to T6) (Table l). However, there was some increase in bug numbers in plots sprayed at hallanthesis and complete-anthesis only. Grain yield did not differ significantly among plots treated at half-anthesis + complete-anthesis and those treated up to hard-dough stage with 3-5 sprays (T3 to T5). In ICSV 1, plots not protected at half-anthesis + complete-anthesis suffered a significant loss in grain yield (Table 2). This suggests that protection during the initial stages of grain development (hall-anthesis to complete-anthesis stages) is most critical for head bug control. However, cultivar susceptibility to bugs at a particular stage of development also seems to affect the extent of grain damage: e.g. ICSV 1 appears to be more susceptible to head bugs during the initial stages of grain development compared with CSH l. ICSV 1 has a small grain and compact panicle, compared with the bold grain and semicompace panicle of CSH 1. These characteristics may also account for the differences in susceptibility of these cultivars to bugs.

Cost-benefit ratios were $>1$ in plots protected with 1-5 sprays from the hall-anthesis and hard- dough stages in CSH l, and between the completeanthesis and hard-dough stages in ICSV 1.

A three-spray schedule was followed during the 1986 rainy season on CSH 5 (Table 3). Plots protected at the complete-anthesis, milk and dough stages gave the maximum grain yicld, followed by those treated at the complete-anthesis and milk stages. These treatments also gave good control of bugs. Plots not treated at complete anthesis suffered a significant reduction in grain yield. Plots protected at the dough stage only, suftered as much bug damage as the untreated check plots. Cost-benefit ratios ranged from $5 \cdot 15$ to $14 \cdot 14$ in plots treated with $1-3$ sprays between the complete-anthesis and dough stages.

During the 1987 rainy season, four sprays were applied in different combinations on CSH 5 (Table $f)$. Plots protected at all lour stages of panicle development yielded $2630 \mathrm{~kg} / \mathrm{h}$ a compared with 1075 $\mathrm{kg} / \mathrm{ha}$ in the unprotected plots. Plots protected at the half-anthesis and/or complete-anthesis and milk stages did not differ significantly from those receiving complete protection. However, plots that were not protected at these stages suffered heavy losses in grain yield. Plots protected with 3-4 sprays of insecticide gave cost-benelit ratios of $3 \cdot 5-4 \cdot 3$.

\section{Ellect of head bug damage on yrain quality}

Grain germination (\%), thousand-grain mass, heavy grain $(\%)$, and grain hardness were significantly higher when the panicles were protected between the hall-anthesis and dough stages, and between the complete-anthesis and dough stages (Table 5). Plots not protected cither at the complete-anthesis and/or milk and dough stages, suffered a significant reduction in grain quality. Similarly, plots not protected either at the complete-anthesis and/or the milk stage showed a greater reduction in grain quality.

Correlation coefficients between grain hardness, 1000-grain mass, percentage floaters and grain germination were positive and significant, indicating that damage by head bugs alfects all the grain quality parameters (Table 6).

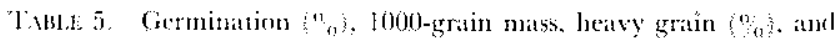
grain hardeness of CSH 5 grain from plots protected at different stages ol patnicle development: 1987 rainy seasom

\begin{tabular}{|c|c|c|c|c|}
\hline Treatment & $\begin{array}{c}\text { Germination } \\
0\end{array}$ & $\begin{array}{l}\text { 1000- } \\
\text { srail } \\
\text { mass }(\mathrm{g})\end{array}$ & 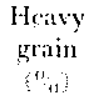 & $\begin{array}{l}\text { Grain } \\
\text { hatdines }\end{array}$ \\
\hline $1 \mathrm{HA}{ }^{a}$ & 115 & 16.81 & 596 & 0.19 \\
\hline $\mathrm{I}^{2} \mathrm{HA}+\mathrm{CA}$ & 10.0 & 17.96 & $59 \%$ & $0.3+1$ \\
\hline $\mathrm{I} 3 \mathrm{HA}+\mathrm{CA}+\mathrm{NI}$ & 10.3 & 17.95 & $7+1.0$ & 0.55 \\
\hline $\mathrm{I}+\mathrm{HA}+\mathrm{CA}+\mathrm{M}+\mathrm{D}$ & 960 & $20 \cdot 15$ & 92.5 & 0.55 \\
\hline $15(A+M+1)$ & $21 \cdot 3$ & $\underline{00} 0.02$ & $83 \cdot 8$ & 0.84 \\
\hline$\Gamma(6)+1)$ & $1.5 \cdot 3$ & 16.17 & $45 \cdot 1$ & 0.73 \\
\hline $17 \mathrm{D}$ & $5 \%$ & 13.71 & $20 \cdot 7$ & 0.25 \\
\hline T8 litreated clecel & $3 \cdot 3$ & $12 \cdot 87$ & 10.0 & 0.4 \\
\hline SF: & $\pm 3 \cdot 01$ & \pm 0.87 & \pm 9.35 & $\pm 0 \cdot(1)+59$ \\
\hline
\end{tabular}

"As in Thth 1 
Dired and indired effect of head but densily al different slayes of pamicle de'topme'nl on grain yield

'The direct and indirect eflects of bug density at difierent stages of panicle development on grain yield are given in Fable 7 . Head bug numbers at the hatl-anthesis to dough stages were significantly and nesatively associated with loss in grain yield, except in bug numbers at the dough stage in ICSV I and CSH 5 during 1987. Correlation coefficients indicated that head bug numbers at the completeanthesis and milk stages had maximum effect on grain yield, and their regression coeflicients were also

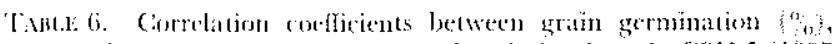

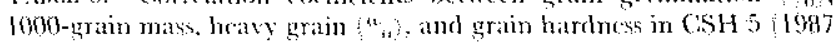
rainy setsons

\begin{tabular}{|c|c|c|c|c|}
\hline & Gormination & $\begin{array}{c}\text { 1000-gratin } \\
\text { maiss }\end{array}$ & $\begin{array}{c}\text { Grain } \\
\text { trarcluess }\end{array}$ & $\begin{array}{c}\text { Hoavy } \\
\text { grain }\end{array}$ \\
\hline \multicolumn{5}{|l|}{ Germination } \\
\hline 1000 -grain mass & $(0.71 *$ & & & \\
\hline Cirain luarduts & $0.57 *$ & $0.593^{*}$ & & \\
\hline Heaty grain & $0+67^{*}$ & $0.83 * *$ & $0.56 *$ & $1 \cdot(0)$ \\
\hline
\end{tabular}

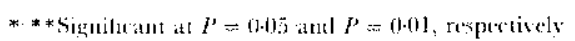

significant (except CSH I and CSH 5 during 1986). Head bug density alter spraying at different stages of panicle development explained $42.6 \%$ of the variance in grain yield for CSH I this percentage was $72.6 \%$ for ICSV 1 , and $82.0 \%$ for CSH 5 . During 1987, the mean numbers of bugs belore and atter spraying at each stage of panicle development were considered for regression analysis. All the regression colficients were significant, and they explained $93.7 \%$ of the variance in grain yield. Thus, bug density before and after spraying during the various developmental stages is important in determining the loss in grain yicld.

The direct eflects of bug numbers at the milk stage were maximum in both CSH 1 and ICSV 1 . Bug numbers at the half- and complete-anthesis stages also showed negative direct effects and on the correlation and regression coefficients. The indirect effects of head bug numbers at these stages through head bug density at the milk stage were also negative. In CSIF 1, bug density at the dough stage also showed considerable negative direct eflects.

Direct eflects of bug density at the completeanthesis, milk, and dough stages were negative in CSH 5 in 1986. The bug numbers at the complete-

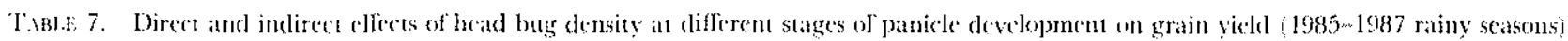

\begin{tabular}{|c|c|c|c|c|c|c|}
\hline $\begin{array}{l}\text { Hall } \\
\text { antlessis } \\
\text { Hot }\end{array}$ & $\begin{array}{c}\text { Complete } \\
\text { anthrsis } \\
\text { CA }\end{array}$ & $\begin{array}{l}\text { Milk } \\
\{\mathrm{M}\end{array}$ & $\begin{array}{c}\text { 1) mugh } \\
\text { (D) }\end{array}$ & $\begin{array}{l}\text { Fard } \\
\text { doughl } \\
\text { (HD) }\end{array}$ & $\begin{array}{c}\text { Correlation } \\
\text { coefficient } \\
\text { (r) }\end{array}$ & $\begin{array}{l}\text { Regression } \\
\text { coeflicimant } \\
\text { (b) }\end{array}$ \\
\hline \multicolumn{7}{|c|}{ CSH 1. 1985 ratiny scasontt } \\
\hline HA -0.13 & -0.02 & -0.25 & -0.06 & $-0.0000^{2}$ & $-0.16 *$ & $-11 \cdot 0$ \\
\hline CA -0.09 & -0.03 & -0.30 & $-0 \cdot 0.2$ & -0.003 & $-0 \cdot 16 *$ & -1.7 \\
\hline $11-0.06$ & -0.02 & -0.50 & -0.08 & 0.008 & $-0.67 * *$ & $-9.1 *$ \\
\hline $\mathrm{D}-0.03$ & $-0 \cdot 0]$ & -0.17 & -0.25 & 0.007 & $-0 \cdot 15)^{*}$ & $-3+4$ \\
\hline $\mathrm{HO}-0.00 \mathrm{l}$ & 0.01 & $-0 \cdot 0)^{2}$ & -0.09 & 0.0 .0 & $-0 \cdot 10$ & $3 \cdot 5$ \\
\hline
\end{tabular}

$r=0 \cdot+7$

Intercet $=1+223^{*}: R^{2}=42 \cdot 6$

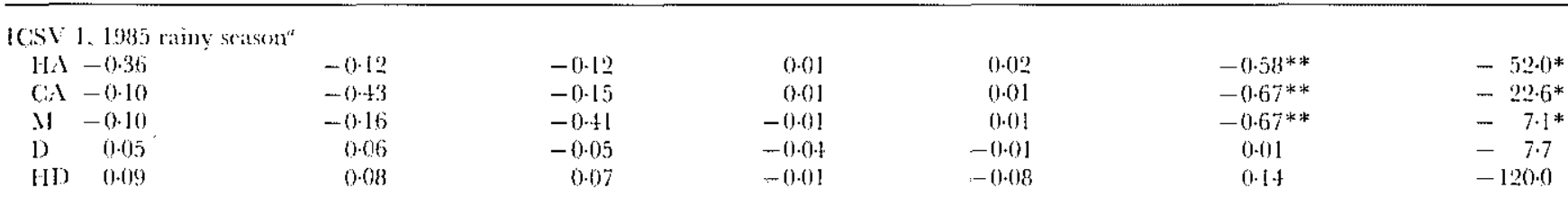

$x=0 \cdot 2 \cdot 4$

Interept $=2 \cdot 480^{*}: R^{2}=72 \cdot 6$

$\begin{array}{cccc}\operatorname{CSH} 5.1980^{\circ} & & \\ \mathrm{CA} & -0.20 & -0.34 & -0.10 \\ \ldots 1 & -0.11 & -0.60 & -0.17 \\ 19 & -0.08 & -0.1 .4 & -0.2 .\end{array}$

$X=0.16$

Intercept $=3296^{*} ; R^{2}=93.7$

\begin{tabular}{rrrr}
\hline CSH $5.1987^{\circ}$ & & & \\
$H A-0.40$ & -0.89 & 0.36 & 0.21 \\
CA -0.27 & -1.30 & 0.72 & -0.0 .4 \\
$\mathrm{H}-0.15$ & -0.97 & 0.97 & -0.63 \\
$\mathrm{D}-0.10$ & -0.05 & 0.63 & -0.96
\end{tabular}

$\mathrm{I}=0 \cdot 0.06$

-0.10
-0.17
-0.2 .4

$-0.64^{* *}$
$-0.89^{* *}$
$-0.76^{* *}$

$-79 \cdot 3$

$-13 \cdot 4^{*}$

$-8.9$

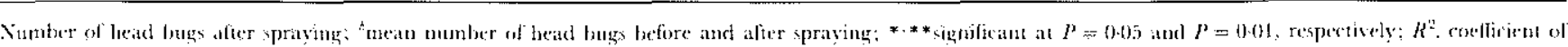

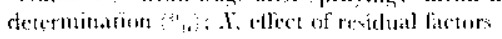


anthesis and dough stages also showed negative indirect effects through head bug density at the milk stage.

On the basis of mean bug numbers before and after spraying during 1987 , the direct effects were negative and greater for head bug density at the half-anthesis, complete-anthesis, and milk stages. However, both the direct and indirect effects of head bug density at the milk stage were positive, inclicating that much of the loss in grain yield is inflicted by bugs before or even after the milk stage.

Head bug density alter spraying explained $52.5 \%$ of the variation in direct and indirect effects for CSH 1, $76 \cdot 1 \%$ for ICSV 1 , and $84.3 \%$ for CSH 5 (during 1986). The mean bug numbers considered during 1987 explained $97 \cdot 3 \%$ of the variance.

\section{Avoidable losses}

Maximum avoidable losses were recorded in ICSV $1(88.6 \%)$, followed by CSH $1(69.9 \%)$ and CSH 5 $(53.9 \%$ in 1986 , and $55.0 \%$ in 1987 ) (Table 8$)$. Loss in grain yield/ha due to one insect/panicle across all stages was $286 \mathrm{~kg}$ in CSH 5 in 1987, $209 \mathrm{~kg}$ in ICSV 1 in $1985,154 \mathrm{~kg}$ in CSH 5 in 1986 and $22 \mathrm{~kg}$ in CSH 1 in 1985. However, when we consider the natural rate of increase in head bug numbers in the unprotected plots and use it in the regression equation, the loss in grain yield/ha was $548 \mathrm{~kg}$ in CSH 5 in $1987,251 \mathrm{~kg}$ in ICSV 1 in $1985,232 \mathrm{~kg}$ in CSH 5 in 1986 and $77 \mathrm{~kg}$ in CSH 1 in 1985 (Table 9).

\section{Economic injury level (EIL)}

Economic injury level (EIL), based on a cost-benefit ratio of 1:1 and Norton's procedure (Norton, 1976)

Tisis.e 8. lixten of awoidable lesses due to head buges in three cultivitrs (1985- 1987 rainy seasons)

\begin{tabular}{|c|c|c|c|}
\hline \multirow[b]{2}{*}{ Coullivar } & \multicolumn{2}{|c|}{ Grain yield ( $\mathrm{kg} / \mathrm{ha}$ ) } & \multirow{2}{*}{$\begin{array}{l}- \text { Avoidable } \\
\text { losses }(0 \%)\end{array}$} \\
\hline & Protected & Unprotected & \\
\hline $\operatorname{CSH} 1(1985)$ & 1677 & 505 & 69.89 \\
\hline ICSV I $19 B 5)$ & 2599 & 296 & 88.61 \\
\hline CSHH 5 (1986) & 2903 & 1339 & 53.83 \\
\hline CSIH 5 (1987) & 2388 & 1075 & 54.98 \\
\hline
\end{tabular}

was $1 \cdot 3-1 \cdot 4$ insects/panicle for CSH 1 (4.5 insects) panicle based on one insect/panicle across all stages and $0.4-0.6$ insects/panicle lor ICSV 1 and CSH 5 (EIL for CSH 5 in 1987 was 0.2 insects/panicle). EILs calculated by the Norton (1976) formula were close to those calculated on the basis of a cost-benefit ratio of $1: 1$ (Table 9).

\section{Discussion}

Grain yield did not differ significantly between plots treated at the half-anthesis to dough stages with 2-1. sprays. However, plots that were not protected at half anthesis and complete an thesis suffered a significant loss in grain yield, indicating that bug damage during the initial stages of panicle development results in severe losses in grain yield. This observation supports carlier findings (Sharma and Leuschner, 1987) that protection around complete anthesis is most critical in preventing head bug damage. Cost-benelit ratios were $>1$ for plots protected with 2-4 sprays between the half-anthesis and dough stages, and thus control of head bugs on high-yielding cultivars is economically feasible, to minimize the losses in grain yield and quality.

Head bug damage caused a severe loss in grain quality. The quality of grain from plots protected with 3-4 sprays at the half-anthesis to dough stages differed substantially from those treated with $1-2$ sprays and hall anthesis and complete anthesis. However, grain yield from plots protected with 1-2 sprays at the half-anthesis and/or completeanthesis stages did not differ significantly from those protected with $3-4$ sprays. Therefore, it seems that even though the quantitative reduction in yicld may not be great, the quality can be severely affected with partial protection or by low levels of head bug infestation.

Avoidable losses due to head bugs ranged from $53.9 \%$ on CSH 5 to $88.6 \%$ in ICSV 1 . Loss of grain yield was generally much greater in ICSV 1 and CSH 5 than in CSH 1. The former has a compact panicle, which is suitable for the growth and survival of bugs, whereas the rate of population build-up on CSH I may be slower because of its semi-loose panicle. T'herefore, sorghum cultivars should mainly

[and.1 9. Ecumomic injury levels (Ell,s) for C. angustahus (1985-1987 rainy seasons)

\begin{tabular}{|c|c|c|c|c|c|c|}
\hline \multirow[b]{2}{*}{ Ciultivar } & \multirow[b]{2}{*}{ Year } & \multicolumn{2}{|c|}{ Loss in grain yield ( $\mathrm{kg} / \mathrm{ha})$} & \multirow[b]{2}{*}{$\begin{array}{l}\text { EIL fonc insect } \\
\text { atcross staytes }\end{array}$} & \multirow[b]{2}{*}{$\begin{array}{c}\text { EIL. based on } \\
\text { natural increase }\end{array}$} & \multirow[b]{2}{*}{ 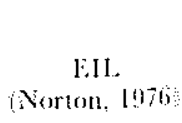 } \\
\hline & & $\begin{array}{l}\text { One insect } \\
\text { per panicle: }\end{array}$ & $\begin{array}{c}\text { Following nalural } \\
\text { increase }\end{array}$ & & & \\
\hline C:SH I & 1985 & 22 & 77 & +1.5 & $1: 3$ & $1 \cdots t$ \\
\hline ICSV I & 1985 & 209 & 251 & 0.5 & $0)+1$ & $0 . \cdot 1$ \\
\hline CSSII 5 & 1986 & $15 \cdot 1$ & 548 & 0.6 & $0 \cdots$ & 0.5 \\
\hline CSIH 5 & 1987 & 286 & 232 & 0.4 & 0.2 & $0 \cdot 2$ \\
\hline
\end{tabular}

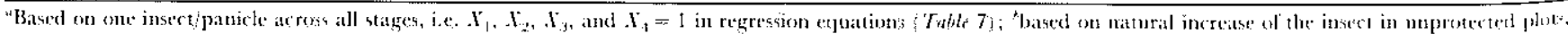

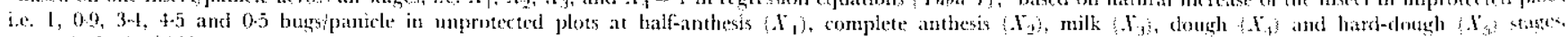

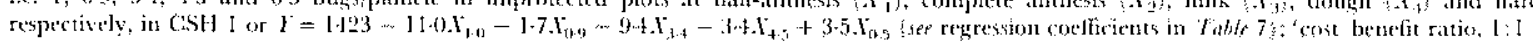


be bred for a loose to semicompact panicle, to minimize losses due to head bugs.

Economic injury levels ranged from 1.3 to $1 \cdot 1 \cdot$ for CSH 1, from 0.4 to 0.6 for ICSV 1 , and from 0.2 to 0.4 Tor CSH 5. EILs based on a cost-benefit ratio of $1: 1$ and those calculated by Norton's formula (Norton, 1976) were closely comparable.

\section{Notes and acknowledgements}

The authors are grateful to the stall of Cereals Entomology for assistance in carrying out this work, and to Dr Murari Singh for his help in statistical analysis.

Approved as J.A. No. 867 by the International Crops Research Institute for the Semi-Arid Tropics (ICRISAT), Patancheru, A.P. 502 324, India.

\section{References}

Bokab, P. K. Ario Mrtra, V. P. (1983). Assessment of losses caused by pest complex on sorghum hybrid cist 5. In: Procededings, Crop Losser Dot lo Instet Pests, pp. 271 288 (ed by B. H. Krishnamurthy Rao and K. S. R. K. Murty). Rajendranagar, Hyderabad, India: Entomological Society of India.

Han., D. G. AND T'He:Tes, G. L. (1982). Yield loss density relationslips of four species ol panicle le'eding bugs in sorghum. Envirommenlal Entomology 11, 738-741.
Hat.liken, L. AN MrkTy, D. S. (1983). A screcning test lor grain hardness in sorghum employing density grading in sodium nitrate solution. Journal of Cereal Srience 1, 265-274.

Lebshinir, K. Nin Sinara, II. C. (1983). Estimation of crop losses due to sorghum panich pests. In: Procecdings, Crop Losses Due to Insect Pests, [p, $201-212$ fed. by B. H. Krishnamurthy Raso and K. S. R. K. Murty). Rajendranagar, Hyderabad, India: Entomological Socicty of India.

Norton, G. A. (1976). Analysis of decision making in crop protection. Agro-Ecosystems 3, 27-11.

Pringo, L. P., Hutcmins, S. H. win Higify, I.. G. (1986). Economic injury tevels in theory and practice. Anmal Revien of Enlomology 31, 34.1 $\rightarrow 368$.

Roovir, L. W. ANs MLRTy, D. S. (1982). Evaluation of sorghum food quality. In: Sorghtom in the Etyhtits: Procetdings of the International Symposium on Sorghum, pp. 571-588. Patancheru, A. P. 502324 , India: International Crops Researd Institute for the Semi-Arid Tropies.

Sirtrma, H. C. (1985a). Future strategies for pest control in sorghum in India. Tropical P'st Managemenl 31, 167-185.

Suskma, H. C. (1985) ). Sereening for host-plant resistance to mirid head bugs in sorghum. In: Proctedings, International Sorghum Entomology Workshop, 16-21 July, 1981, Texas AEM University, College Station, Texas, USA, [p]. 317\%336. Patancheru, A. P. 502 32. India: International Crops Research Institute for the Semi-Arid 'Tropics.

Suarma, H. C. and Lecsemise, K. (1987). Chemical control of sorghium head hugs (Imiptera:Miridac). Crop Protection 6, $334-340$.

Received 13 January 1989

Revised 18 June 1989

Accepted 3 July 1989 